\title{
A survey of domestic wells and pit latrines in rural settlements of Mali: Implications of on-site sanitation on the quality of water supplies
}

\author{
P. Martínez-Santos ${ }^{\mathrm{a},}{ }^{*}$, M. Martín-Loeches ${ }^{\mathrm{b}}$, N. García-Castro ${ }^{\mathrm{b}}$, D. Solerac ${ }^{\mathrm{c}}, \mathrm{S}$. Díaz-Alcaide $^{\mathrm{a}}$, \\ E. Montero ${ }^{\mathrm{a}}$,J.García-Rincón ${ }^{\mathrm{b}}$
}

\footnotetext{
a Departamento de Geodinámica, Facultad de Ciencias Geológicas, Universidad Complutense de Madrid, C/Iosé Antonio Novais 12, 28040, Madrid, Spain

b Departamento de Geología, Geografía y Medio Ambiente, Facultad de Ciencias Ambientales, Universidad de Alcalá de Henares, Campus Universitario, Ctra, Madrid-

Barcelona, Km 33,600, Alcalá de Henares, 28801, Madrid, Spain

${ }^{c}$ Geólogos Sin Fronteras, C/El Bosque 5, Pozuelo de Alarcón, 28224, Madrid, Spain
}

\section{A B S T R A C T}

On-site sanitation is generally advocated as a means to eradicate the health hazards associated with open de- fecation. While this has provided a welcome upgrade to the livelihoods of millions of people in low-income countries, improved sanitation facilities are increasingly becoming a threat to domestic groundwater-based supplies. Within this context, a survey of pit latrines, domestic wells and improved water sources was carried out in a large rural village of southern Mali. All households were surveyed for water, sanitation and hygiene habits. Domestic wells and improved water sources were georeferenced and sampled for water quality $(\mathrm{pH}$, electric conductivity, temperature, turbidity, total dissolved solids, thermotolerant coliforms, chloride and nitrate) and groundwater level, while all latrines were inspected and georeferenced. A GIS database was then used to evaluate the proportion of water points within the influence area of latrines, as well as to underpin multiple regression models to establish the determinants for fecal contamination in drinking supplies. Moreover, an appraisal of domestic water treatment practices was carried out. This revealed that nearly two-thirds of the population uses bleach to purify drinking supplies, but also that domestic-scale treatment as currently im- plemented by the population is far from effective. It is thus concluded that existing habits could be enhanced as a means to make water supplies safer. Furthermore, population, well and latrine density were all identified as statistically significant predictors for fecal pollution at different spatial scales. These findings are policy-relevant in the context of groundwater-dependent human settlements, since many countries in the developing world currently pursue the objective of eliminating open defecation.

Keywords: Groundwater protection, Open defecation Sanitation, Human rights Town planning, Sustainable development goals, Spatial analysis

\section{Introduction}

Adequate access to water and sanitation is essential for human dignity and wellbeing. Water is not only required for basic daily activities such as hydrating, cooking, washing or hygiene, but is also a key input for food security (United Nations, 2015a). On the other hand, sanitation systems are needed to guarantee the quality of water resources, thus protecting the environment and our very own drinking supplies. Sanitation also provides an essential service for living in human dignity and contributes to prevent disease in a number of ways. Despite these facts, official estimates suggest that 663 million people still lack sustainable access to safe drinking water (UNICEF/WHO, 2015), a figure which is most likely an underestimate (Martinez-Santos, 2017). Furthermore, just $68 \%$ of the world's population uses improved sanitation facilities. It is thus no wonder that "ensuring access to water and sanitation for all" has been listed as a core target of the Sustainable Development Goals for the year 2030 (United Nations, 2015b).

Groundwater resources are widely relied upon in sub Saharan Africa, particularly in those regions where rainfall is absent for several months each year. Areas where ground water supplies are scarce or nonexistent often have the greatest problems with health and poverty (MacDonald et al., 2008). It is estimated that Africa's shallow aquifers (<80 m depth) currently underpin the daily life of 200 million people (Foster and Garduño, 2013). Groundwater is often extracted from boreholes, most of which are owned and operated by communities. Water is then supplied to the public by means of hand pumps or standpipes. Though more vulnerable to drying up periodically and to contamination, shallow domestic wells are also popular in many countries (Mkandawire, 2008; Pritchard et al., 2008; Wanke et al., 2014; Machado and Bordalo, 2014; Okotto et al., 2015; Liddle et al., 
2015). This is largely because digging provides an affordable means to own a private water source, which in turn prevents people from walking the distance and queuing at community water points.

In the last decades, the advent of on-site sanitation has provided a welcome upgrade to the livelihoods of millions of people. However, improved sanitation facilities have also become a threat to domestic water supplies in many low-income regions (Dzwairo et al., 2006; Kiptum and Ndambuki, 2012; Nyenje et al., 2013; Shivendra and Ramaraju, 2015; Sorensen et al., 2016). Pit latrines are frequently constructed in close proximity to wells and boreholes, often based on ad hoc considerations such as space constrains or simple convenience (Islam et al., 2016). Moreover, pits are frequently unlined. Since latrine effluents contain harmful pathogens, including bacteria, viruses, protozoa or helminths (WHO, 2011), their very presence poses a direct risk to shallow groundwater and endangers human health. Fecal contamination in groundwater supplies usually translates into widespread gastro-intestinal disease among groundwater-dependent populations. Diarrheas may result in dehydration and malnutrition, poor intellectual development or even death (WHO, 2017a). It is estimated that about three quarters of child deaths due to diarrhea occur in just fifteen countries, most of which are located in Asia and sub Saharan Africa. One of these is the Republic of Mali, where diarrheas account for nearly 21,000 children deaths every year (UNICEF/WHO, 2009).

Open defecation has long-since been known to be a major public health issue, as it spreads diseases such as diarrhea, intestinal worms, typhoid or cholera (WHO, 2017b). Thus, its elimination has increasingly been recognized as a top priority for improving health, nutrition and productivity (UNICEF/WHO, 2015). The flipside of the coin is that latrine pressure on groundwater supplies can only be expected to grow, as on-site sanitation has been promoted throughout the African continent as an alternative to defecation in the open. In the context of the Millennium Development Goals, Mali has embraced different initiatives to prioritize improved sanitation facilities in rural communities. While this is a welcome step towards improving the living conditions of the population (70\% of which inhabits rural settlements), this research argues that the inherent dangers are yet to be fully accounted for. Based on a field survey carried out in the southern part of the country, this paper presents three objectives. The first one is to establish how uncontrolled on-site sanitation poses a risk to domestic water supplies in villages of low-income countries. The second goal is to evaluate whether decentralized water treatment practices as currently implemented by the population in the study area are sufficient to cope with the threat of fecal pollution. Finally, the third objective is to explore potential correlations between fecal contamination markers in groundwater with spatially-distributed variables such as population, well or latrine density so as to be able to determine the key factors behind groundwater contamination and delineate the riskier areas.

\section{Geographical setting}

Field data was collected in Beleko-Soba, the chief village within the rural commune of Djedougou, during January 2017 (Fig. 1A). This study focuses on the three westernmost neighborhoods of the village (Diawarrala, Dougouyala Ouest and Fyenkala), whose joint population is 1500 .

The area presents a hot tropical climate. Temperatures are high throughout the year, the average standing at $26^{\circ} \mathrm{C}$. Rainfall amounts to $800 \mathrm{~mm} / \mathrm{yr}$ and takes place almost exclusively between June and September. There are no major streams or rivers in the immediate vicinity of the study site. Thus, the population relies exclusively on groundwater.

From the hydrogeological standpoint, the study area is located within the Infracambrian Metasedimentary aquifer of southern Mali. The relatively small size of the site (about $0.5 \mathrm{~km}^{2}$ ), coupled with the available borehole information, suggests a relatively monotonous geological profile (Fig. 2). Thus, the uppermost layer is made up of a hard laterite crust whose thickness can exceed five meters in some areas. Immediately beneath, there is an unconsolidated layer made up of clays with intercalations of fine sand. This formation, which typically ranges between 10-15 m, lies on top of the regional sandstone aquifer, whose depth exceeds one-hundred meters and which is underlain by a gneiss basement.

Regional groundwater flow is ultimately controlled by rivers Bani and Banifling (García-Castro and García-Rincón, 2017), both of which are tributaries to river Niger. At the village scale, groundwater is observed to flow from the southwest to the northeast (Fig. 1B). The water table depth ranges between five and fifteen meters at the end of the dry season, and remains closer to the surface, i.e. one to three meters, during the rainy months. Groundwater is accessed either through improved water sources or through domestic wells. An improved water source is defined as one that, by nature of its construction or through active intervention, is protected from outside contamination, in particular from contamination with fecal matter (UNICEF, 2014). This definition encompasses household connections, public standpipes, boreholes, protected dug wells, protected springs and rainwater collection. It leaves out unimproved sources such as unprotected wells and springs or surface waters. Public improved water sources include three boreholes equipped with hand pumps and one additional borehole serving two public standpipes (Figs. 3 and 4). The standpipes are connected to an elevated tank located approximately $500 \mathrm{~m}$ to the west of the study area. This means that there is approximately one public water point per every 235 people. On paper, this is an adequate ratio, since a hand pump or a standpipe can be expected to serve $300-500$ people. Additionally, there are some improved sources which are privately-owned and operated. These include one hand pump and two standpipes, and could not be surveyed.

Domestic wells are shallow pits excavated by means of picks and shovels. In the study area these are typically less than $15 \mathrm{~m}$ deep and their diameter usually ranges between one and two meters. Despite the relative abundance of improved sources, our field survey reveals that over $80 \%$ of the households own a shallow well. As explained earlier, these are preferred by many people because they are cheaper than boreholes and allow users to avoid potentially long trips to public water sources.

There is no public sanitation system. Direct inspection shows that close to $85 \%$ of the households own pit latrines. These are built much like domestic wells, but are shallower (typically 2-6 m) and wider $(1 \times 1$ to $2 \times 2 \mathrm{~m})$. Also, latrines are typically sheltered and covered with a concrete slab. In the vast majority of cases, latrines are unlined, meaning that feces may come directly in contact with groundwater. This is particularly true of the rainy season, when the water table rises close to the ground level.

Groundwater contamination from latrines must be understood in the light of the geological setting (Fig. 2). The laterite crust can be considered nearly-impervious for practical purposes. Clay also presents a very low permeability, which implies that the upper geological units provide some protection against contamination associated with the infiltration of surface runoff. However, contamination due to lateral groundwater flow can still be expected because domestic wells and pit latrines often break through both layers. Even when they do not, the sandy lenses embedded in the clay matrix are permeable. This implies that wells and latrines may come in contact through them.

\section{Materials and methods}

\subsection{Field survey}

A survey of all water and sanitation facilities was carried out in the three neighborhoods towards the end of the dry season 2017. A total of 119 domestic wells were characterized and surveyed for water table depth and water quality $(\mathrm{pH}, \mathrm{EC}$, temperature, turbidity, thermotolerant coliforms). All five public water points were also checked for 


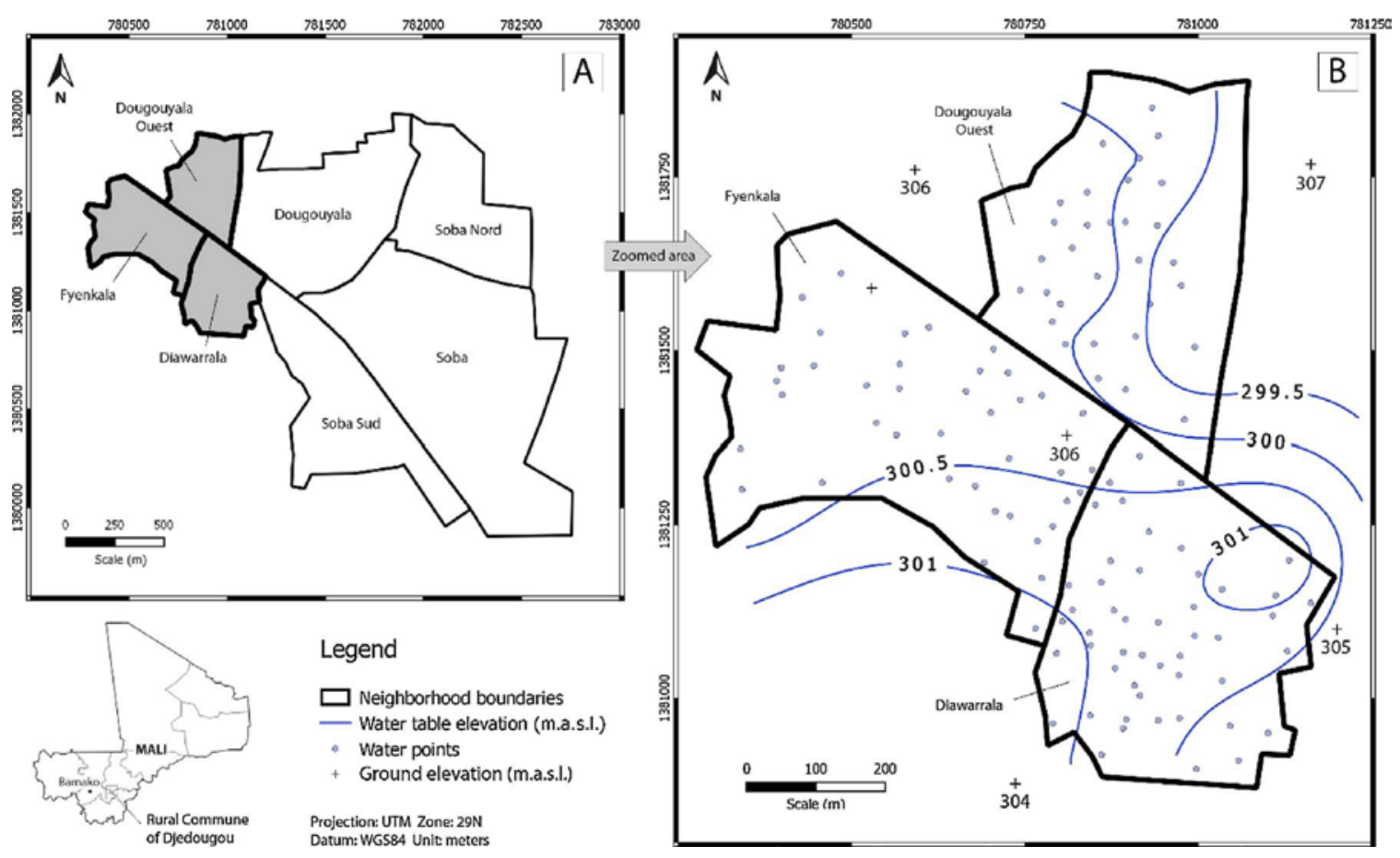

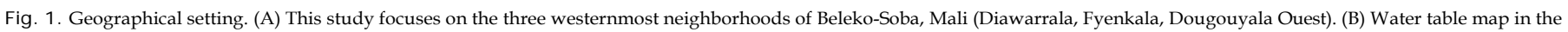
three neighborhoods under study (January 2017, early dry season).

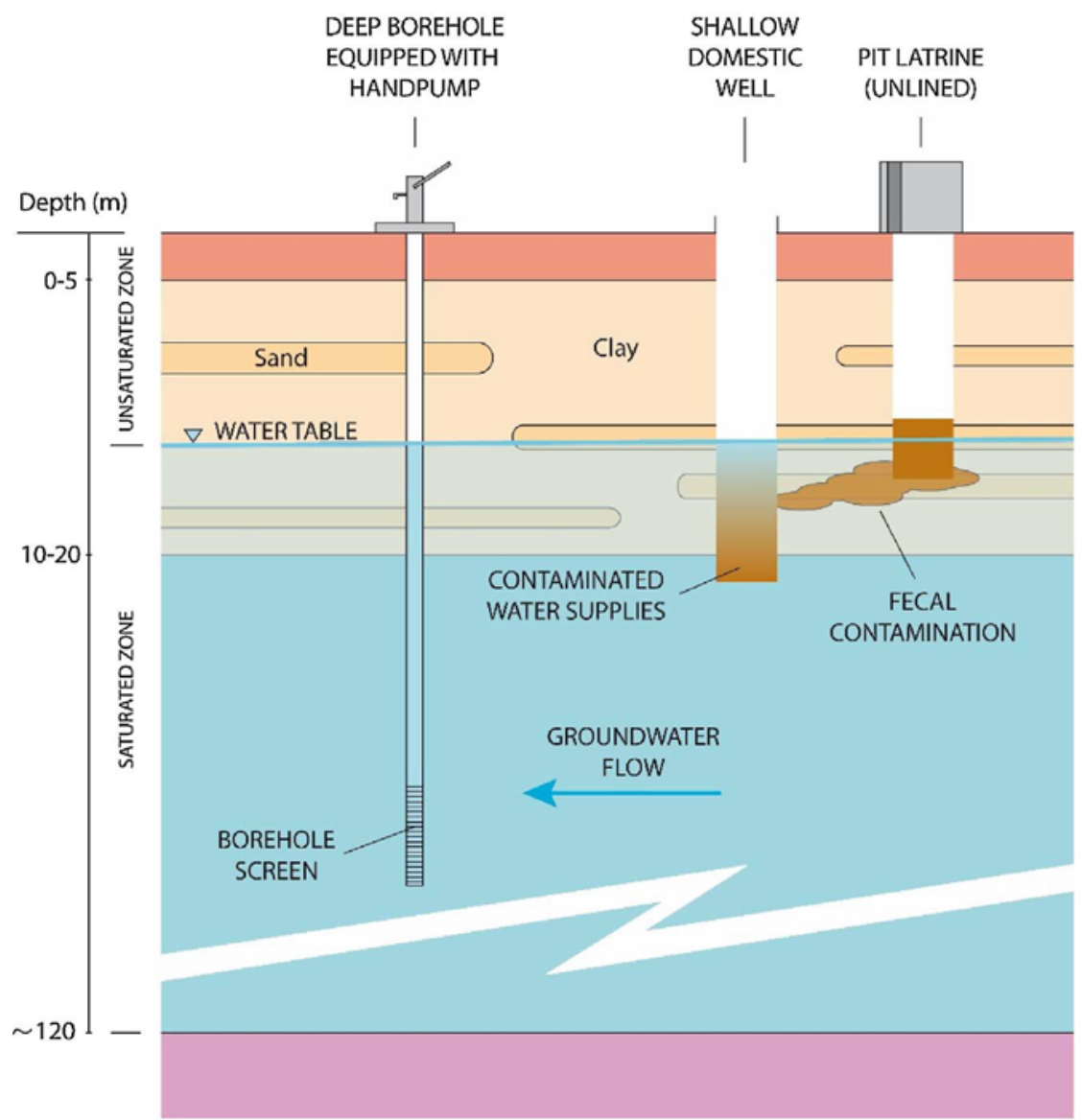

Age; lithology (type of porosity) Aquifer name

Quaternary; laterite

Quaternary; clays with sands (intergranular)

Precambrian; metasediments (intergranular/fractured) Infracambrian metasedimentary aquifer

Precambrian; gneiss

Fig. 2. Schematic geological section (the vertical scale has been distorted to facilitate viewing). 


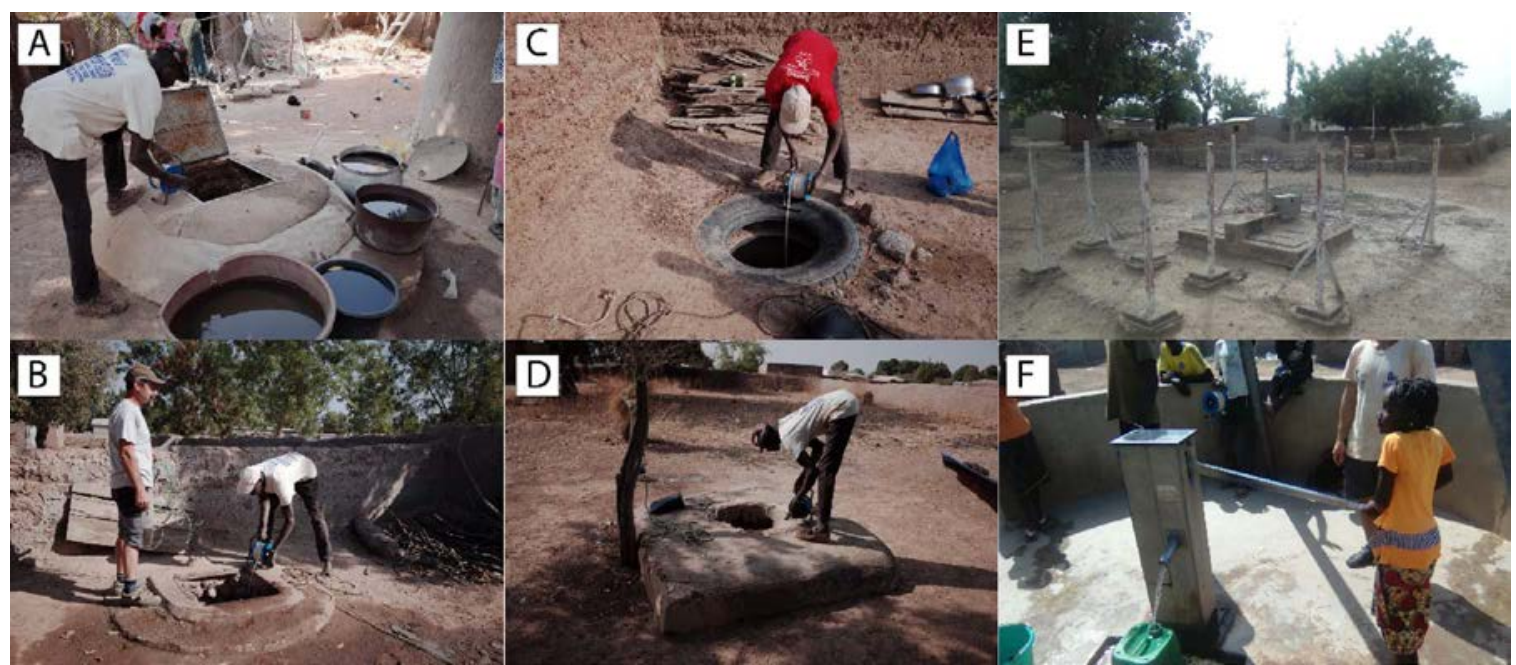

Fig. 3. Types of water sources in the study site. (A) Protected well; (B) Protected well with lid in poor condition (limited protection); (C) Unprotected well; (D) Protected well with no lid (limited protection), (E) Public standpipe; (F) Public hand pump.

serviceability and water quality. Additionally, forty of the water samples were tested for major and minor chemical components, as well as for heavy metals. All 126 domestic latrines in the area were inspected and georeferenced.

Surveys in tropical regions are typically carried out in two stages, i.e. under wet and dry conditions. In this case, however, a single dry season survey was considered sufficient for practical purposes. This is because one of the main goals of this research is to show how building pit latrines (desirable) can lead to the contamination of domestic supplies (undesirable). A cause-effect relation is best established if the existing conditions allow to discriminate the effects of each type of contamination. Under wet conditions this is difficult because well

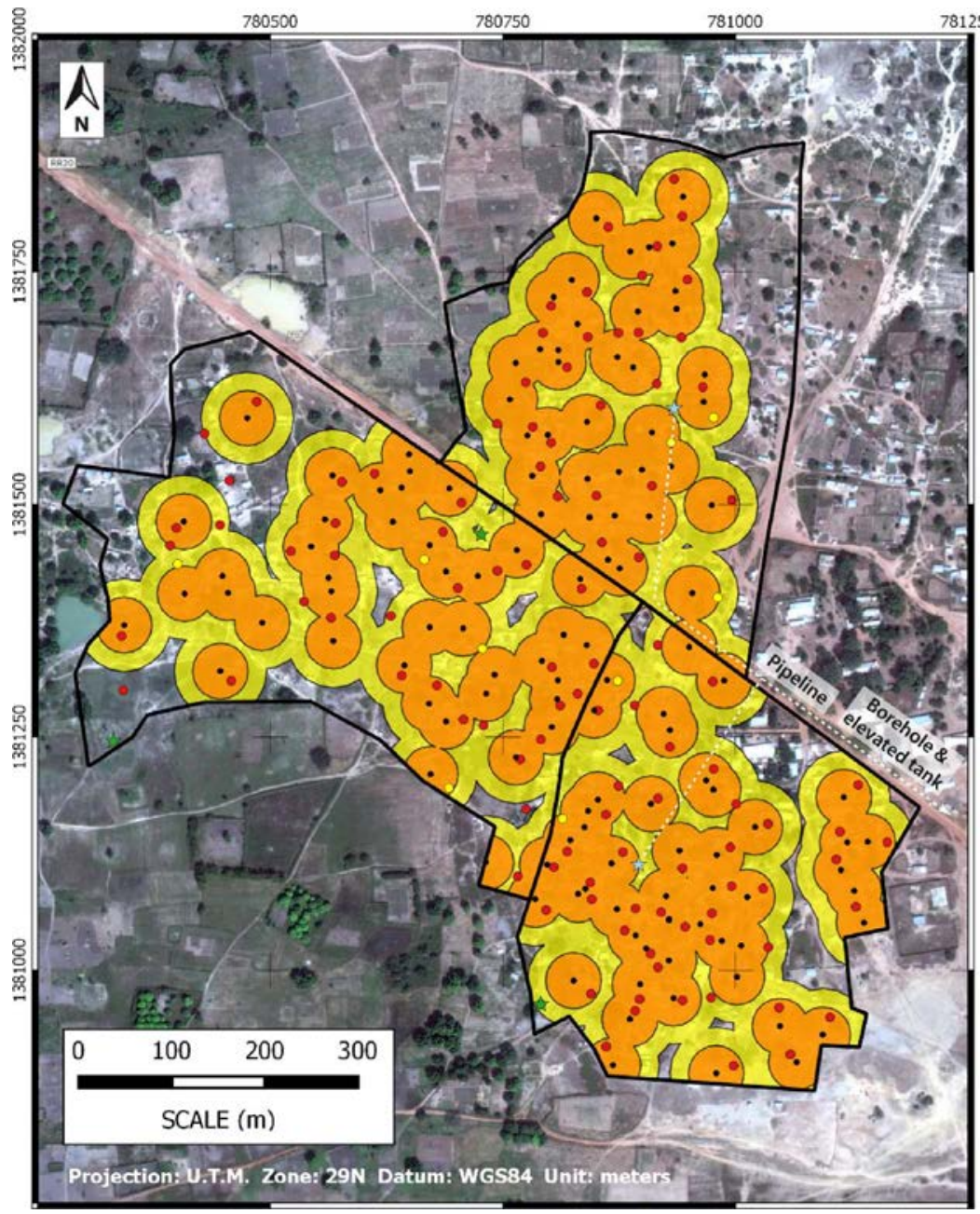

\section{Legend}

Neighborhood boundaries

\section{Water \& sanitation facilities}

- Latrines

* Standpipes

* Borehole with hand pump

Domestic wells (TTC CFU/100ml)

- 0 - 1

- $1-10$

- $10-50$

\section{Distance to nearest latrine}

$<30$ meters

$<50$ meters 
In situ questionnaire and household survey items.

\begin{tabular}{|c|c|c|}
\hline Questions & Visual inspection of facilities & Additional information \\
\hline \multirow[t]{2}{*}{ How many people inhabit the household (adults/children)? } & Is the well protected? If so, how? & Well and latrine coordinates \\
\hline & Is the protection scheme damaged? & Location of both on a printed map \\
\hline Do they drink water from the well? If not, why not? & Was the well covered during the visit? & Water table level \\
\hline \multirow{4}{*}{$\begin{array}{l}\text { Do they perform some kind of water treatment? If so, how and } \\
\text { how often? }\end{array}$} & \multirow[t]{4}{*}{ Can excess water accumulate around the well? } & $\mathrm{pH}$ \\
\hline & & Electric conductivity \\
\hline & & Turbidity \\
\hline & & Temperature \\
\hline Do they cover the well? & Were there contamination sources around the well? If so, which ones? & Total dissolved solids \\
\hline Do they drink water from a public source? If so, which one? & $\begin{array}{l}\text { Could household members produce a sample of the product they use to } \\
\text { treat drinking supplies? }\end{array}$ & Photograph of the well \\
\hline Do they own a latrine? If so, where is it located and why? & If there is a latrine, what kind of latrine is it? & Photograph of latrine \\
\hline
\end{tabular}

contamination may take place in three different ways: (1) direct inflow of contaminated surface runoff into the well; (2) contaminated runoff infiltrates through the soil, reaching the saturated zone before flowing into the well; or (3) contaminated groundwater flow from latrines to wells. However, in the absence of surface runoff (i.e during the dry season), the first two contamination mechanisms do not take place. In settings such as the one at hand this becomes particularly clear, as there is no rain between November and May.

The field survey included a semi-structured questionnaire and a visual inspection of household facilities and conditions. The questionnaire was developed based on the information collected during a field survey of over one hundred domestic wells that was carried out across all seven neighborhoods of Beleko-Soba in June 2016. Questions were posed to the most senior member of the household available. A local translator was hired for this purpose. Table 1 outlines the main aspects of the questionnaire.

Since this work focuses on the interactions of on-site sanitation with domestic water supplies, no attempt was made to establish a statistical correlation between water quality and epidemiological data. However, the existing information suggests that water borne disease is widespread. According to the information facilitated by the local health center (year 2016), gastrointestinal illnesses are behind approximately $22 \%$ of the total medical consultations, ranking second to malnutrition during the dry months and to malaria in the wet season.

\subsection{Water-testing procedures}

Water samples were tested on-site for electric conductivity, total dissolved solids, temperature and $\mathrm{pH}$ using a Hannah HI-98121 multiparametric device, while turbidity was measured by means of a standard field turbidimeter.

Though of limited value, thermotolerant coliforms (TTC) provide an acceptable indicator of fecal pollution in drinking water sources (WHO, 2011). In this case, TTC were chosen as indicator bacteria due to logistic constrains. TTC are measured by quantifying the number of colony forming units (CFU) per $100 \mathrm{ml}$ of water. International standards establish $0 \mathrm{CFU} / 100 \mathrm{ml}$ as the threshold for drinking purposes, though a concentration of 1-10 CFU is sometimes considered tolerable (WHO, 2002). All collected samples were refrigerated, kept in the dark and filtered prior to microbiological analyses. Cultures were prepared in petri dishes within eight hours of collection and incubated with an Oxfam-Delagua portable laboratory at a constant temperature of $44^{\circ} \mathrm{C}$ for eighteen hours (OXFAM, 2009). Colony forming units were counted within ten minutes of retrieval from the incubator. Quantities in excess of $50 \mathrm{CFU}$ were considered too numerous to count.

Nitrate and chloride are frequently used as chemical markers of fecal pollution (Graham and Polizzotto, 2013). Both are present in high concentrations in excreta and are mobile in the sub-surface. In this case, forty samples were collected for the purpose of analyzing these constituents. All five public water points were tested. The remainder of the samples (e.g. those corresponding to domestic wells) were collected randomly across the study area.

\subsection{Spatial database}

All results were compiled into a spatial database. QGIS 2.12 Lyon was used for this purpose. QGIS is a free, open-source software licensed under the GNU General Public License. High-resolution satellite images of the commune were downloaded from Google Earth using SASPlanet, which is also freeware and open source (SASPlanet, 2014).

Many national standards and guidelines in sub-Saharan Africa determine wellhead protection areas as a fixed distance between latrines and groundwater sources (Parker and Carlier, 2009). The minimum allowable space is often based on the assumption that a distance equivalent to 25 days travel time is usually sufficient to reduce concentrations of fecal indicator bacteria (e.g. E. coli) to levels where detection within most samples is unlikely (ARGOSS, 2001). A distance of $30-50 \mathrm{~m}$ is a recurrent benchmark (Harvey, 2007; Parker and Carlier, 2009). This could be considered adequate in the case at hand based on a simple application of Darcy's law, which states that the flow rate in porous media is proportional to the hydraulic conductivity, the flow section and the hydraulic gradient. It is known, however, that travel time may be significantly faster under certain hydrogeological conditions (for instance, in fractured media), and that some pathogens have a longer life than indicator bacteria (Taylor et al., 2004; Harvey, 2007).

Buffer areas of 30 and $50 \mathrm{~m}$ were delineated around latrines in order to (a) calculate the extent of the village surface area within a "safe distance" from a latrine; and (b) establish the proportion of domestic wells and improved water sources located at a "safe distance" from latrines. This procedure takes into account that the influence area of a latrine may exceed the boundaries of a neighborhood.

Latrine and building density have also been proposed as potential determinant for fecal pollution in domestic wells (Wright et al., 2013). Thus, heat map was developed in order to establish whether latrine density correlates with increased fecal pollution in the study area. A similar reasoning and approach applies to population density, as latrines can be expected to provide a heavier pollutant load in those households hosting a larger number of people.

\section{Results}

\subsection{Household survey results}

Survey results are directly representative of the living conditions of approximately 1200 people. This is equivalent to $80 \%$ of the total population of the three neighborhoods. Fig. 3 provides some typical examples of water sources in the area. Field inspection reveals that just $25 \%$ of the domestic wells present some sort of protection (concrete apron, cover, fence, parapet). Moreover, in $7 \%$ of the cases the scheme was either too damaged or too old to provide any actual defense against contamination. Approximately $75 \%$ of the wells were found to be completely unprotected. These figures are particularly important in 
Table 2

Well location in relation to pit latrines in each neighborhood.

\begin{tabular}{lllll}
\hline Neighborhood & $\begin{array}{l}\text { Total } \\
\text { wells }\end{array}$ & $\begin{array}{l}\text { Wells within } \\
30 \mathrm{~m} \text { of a } \\
\text { latrine }(\%)\end{array}$ & $\begin{array}{l}\text { Wells within } \\
30-50 \mathrm{~m} \text { of a } \\
\text { latrine }(\%)\end{array}$ & $\begin{array}{l}\text { Wells located } \\
\text { more than } 50 \mathrm{~m} \\
\text { away }(\%)\end{array}$ \\
\hline Diawarrala & 38 & 71.1 & 23.7 & 5.3 \\
Fyenkala & 50 & 94.0 & 6.0 & 0.0 \\
$\begin{array}{l}\text { Dougouyala O. } \\
\text { Total }\end{array}$ & 31 & 93.5 & 6.5 & 0.0 \\
& 119 & 86.5 & 11.8 & 1.7 \\
\hline
\end{tabular}

view of the drinking water habits. While $82 \%$ of the households use improved water sources at least on occasion, 58\% drink water from domestic wells on a consistent basis. Just $42 \%$ declared to use the water from improved water sources to drink and the well for everything else. Reasons for not drinking well water included health issues $(29 \%)$, unpleasant taste (22\%), the presence of an improved water source nearby $(22 \%)$, turbidity $(20 \%)$, the presence of obvious contaminant sources $(4 \%)$ and other considerations $(2 \%)$.

The hand pump located near the boundary between Fyenkala and Dougouyala Ouest was the source of choice for $60 \%$ of improved source users (Fig. 3F). About 22\% used the public standpipes, $11 \%$ the hand pump located in southern Diawarrala and just $7 \%$ the one in southern Fyenkala.

Potential contamination vectors were detected in close proximity to all domestic wells. Aside from latrines, identified sources include freeroaming or stabled animals, uncontrolled waste disposal, manure piles and small agricultural plots. All this implies that unprotected wells can be assumed to act as additional vectors for groundwater contamination. Deficient practices such as leaving water containers lying around were also found to be common.

Interestingly, water contamination is perceived as an issue by many people. About $57 \%$ of the households declared to perform some kind of domestic treatment before drinking well water. Bleach was involved in all instances, although the ways and the frequency in which it was used were very different. In most cases, a member of the household (normally the head of the family) declared to be in charge of the job and explained that the process consisted in spilling a 0.51 bottle of bleach into the well. Frequencies oscillated between once a week and once a year. In a small number of households $(6 \%)$, treatment was performed by releasing one or two droplets of bleach in the water containers (e.g. buckets or jerry-cans) prior to consumption.

\subsection{Latrine map}

Most people in this rural region of Mali build their own houses from scratch. According to the information provided by the local authorities, when young men come of age they are endowed with a plot of land which they can freely develop. This means that they have a choice as to where to place all household facilities, including the well and the latrine. The field survey provides some valuable insights as to how people choose these spots. Approximately $24 \%$ of the interviewees explained that they picked the location of the latrine so as to keep it "far away" from the well, while a further $13 \%$ said that the latrine was placed downstream the well to prevent latrine overflows during the rainy reason from contaminating water supplies. This means that over onethird of the latrines were located with some kind of sanitary criteria. Additional motives included distance to the house (9\%), the availability of physical space $(7 \%)$, the fact that the latrine was already there when they moved in $(5 \%)$ or ease of access $(2 \%)$. About $40 \%$ of the households provided no reasons, but this figure should be handled with care because in some cases the head of the family (i.e. the person who decided where to build the latrine) was absent at the time of the visit.

These outcomes suggest that wellhead protection distances are either unknown to or disregarded by a large share of the population. This can be attributed to several reasons. Perhaps the most important one is
Table 3

Water quality results. In situ parameters for 119 water samples.

\begin{tabular}{lllllll}
\hline Item & $\mathrm{pH}$ & $\mathrm{EC}(\mathrm{mS} / \mathrm{cm})$ & $\mathrm{TDS}$ & $\mathrm{T}\left({ }^{\circ} \mathrm{C}\right)$ & Turbidity $(\mathrm{NTU})$ & Water depth $(\mathrm{m})$ \\
\hline Max. & 6.92 & 0.50 & 0.25 & 30.5 & 30 & 8.40 \\
Min. & 5.05 & 0.03 & 0.02 & 25.7 & $<5$ & 3.10 \\
Avg. & 6.19 & 0.17 & 0.08 & 28.3 & 7 & 6.11 \\
StDev. & 0.36 & 0.11 & 0.05 & 1.1 & 5 & 1.11 \\
\hline
\end{tabular}

that there are no municipal guidelines for on-site sanitation. The problem is aggravated by the fact that, according to the survey, many people do not seem to make the connection between pit latrines and well contamination. Furthermore, most land plots are too small to accommodate a 30 or $50 \mathrm{~m}$ buffer, and even when these large enough, the well may be within the influence area of the neighbor's latrine.

Diawarrala was found to present the highest density of wells (288) and latrines (335) per square kilometer. In contrast, Fienkala presents a density of 241 wells and 220 latrines per square kilometer, and Dougouyala Ouest 197 and 249, respectively. Fig. 4 presents a map with the influence area of pit latrines in relation to domestic wells. Approximately half of the total surface area of the three neighborhoods is observed to fall within $30 \mathrm{~m}$ of a latrine, while about $80 \%$ is within $50 \mathrm{~m}$. In the case of Diawarrala, the percentages are $59 \%$ and $90 \%$, respectively; while these amount to $49 \%$ and $75 \%$ in Dougouyala Ouest and $46 \%$ and $77 \%$ in Fyenkala. The abundance of latrines necessarily implies that a large number of domestic water supplies are located in close proximity to potential sources of fecal contamination. Indeed, the spatial database shows that approximately $86 \%$ of the wells are within $30 \mathrm{~m}$ of a pit latrine, $12 \%$ between 30 and $50 \mathrm{~m}$, and just $2 \%$ outside the influence area (Table 2). Only one of the five public water points was located at a theoretically safe distance.

\subsection{Water quality results}

Table 3 presents the results of in situ water quality measurements. Overall, groundwater is slightly acidic and presents relatively low electric conductivity. Turbidity could be identified at first sight (over 5 NTU) in approximately one-third of the samples.

Groundwater contamination was found to be widespread (Table 4). About $73 \%$ of the samples rendered over 50 CFU/100 ml TTC, and 7\% less than 10. Just two samples, one corresponding to a hand pump and the other one to a protected well, rendered zero CFUs. The hand pumps yielded 0,6 and $25 \mathrm{CFU}$, while the standpipes yielded 2 and 4, respectively. This suggests that improved water sources may provide some kind of additional protection over domestic wells, but also that they are just as likely to get contaminated if subject to a significant pollutant load. In fact, parallel work by Martinez-Santos et al. (2017) shows that water quality in the five public sources located within these three neighborhoods is generally better than in most nearby villages. These authors found that just 15 of the 86 improved sources within all 30 villages of the commune (total population 36,000 ) tested negative for thermotolerant coliforms, and that only a further 23 were within tolerable values $(1-10 \mathrm{CFU} / 100 \mathrm{ml})$.

The field survey was carried out in the early part of the dry season, about three months after the last rain. As a higher risk of groundwater contamination can be expected during the wet months (Cronin et al., 2006; Nienie et al., 2017), the prevalence of TTC in groundwater samples suggests that fecal contamination poses a year-round health threat across all three neighborhoods.

Nitrate concentration ranges between 1 and $72 \mathrm{mg} / \mathrm{l}$, the average standing at $22 \mathrm{mg} / 1$ and the standard deviation at $16 \mathrm{mg} / 1$. Several wells were observed to exceed the $50 \mathrm{mg} / 1$ threshold for drinking water supplies of the World Health Organization (WHO, 2011). Chloride ranges between undetectable and $48 \mathrm{mg} / \mathrm{l}$, with an average of $13 \mathrm{mg} / 1$ and a standard deviation of $11 \mathrm{mg} / 1$ (Fig. 5). An acceptable linear 
Table 4

Water quality results for fecal markers. TTC results expressed in $\mathrm{CFU} / 100 \mathrm{ml}$; $\mathrm{NO}^{3}$ and $\mathrm{Cl}^{-}$results expressed in $\mathrm{mg} / \mathrm{l}$.

\begin{tabular}{|c|c|c|c|c|c|c|c|c|c|c|c|c|}
\hline \multirow[t]{2}{*}{ Item } & \multicolumn{3}{|l|}{ Total } & \multicolumn{3}{|c|}{ Diawarrala } & \multicolumn{3}{|c|}{ Fyenkala } & \multicolumn{3}{|c|}{ Dougouyala Ouest } \\
\hline & TTC & $\mathrm{NO}_{3}$ & $\mathrm{Cl}^{-}$ & TTC & $\mathrm{NO}_{3}$ & $\mathrm{Cl}^{-}$ & TTC & $\mathrm{NO}_{3}$ & $\mathrm{Cl}^{-}$ & TTC & $\mathrm{NO}_{3}$ & $\mathrm{Cl}^{-}$ \\
\hline Samples & 119 & 40 & 40 & 43 & 17 & 17 & 45 & 12 & 12 & 31 & 11 & 11 \\
\hline Max. & $>50$ & 72 & 48 & $>50$ & 72 & 48 & $>50$ & 3 & 13 & $>50$ & 35 & 25 \\
\hline Min. & 0 & 1 & 0 & 0 & 9 & 5 & 2 & 34 & 0 & 4 & 1 & 0 \\
\hline Avg. & - & 22 & 13 & - & 33 & 20 & - & 16 & 8 & - & 12 & 7 \\
\hline StDev. & - & 16 & 11 & - & 16 & 13 & - & 9 & 4 & - & 11 & 2 \\
\hline
\end{tabular}

correlation was found for the concentration of both constituents across all forty samples $\left(r^{2}=0.80\right)$. The nitrate to chloride ratio is in the order of 2.3, which is roughly to be expected in groundwater affected by unsewered sanitation (MacDonald et al., 2005). The highest concentrations of chloride and nitrate were found in Diawarrala, more so towards the southern part of the neighborhood, coinciding approximately with the area of greater latrine density (Fig. 6). However, the spatial correlation is not so clear in the case of other high latrine-density zones. This could be attributed to the fact that some high latrinedensity areas were not sampled for chloride or nitrate. The implications are discussed further on.

\section{Discussion}

\subsection{Balancing on-site sanitation with the reliance on domestic wells}

Fixed protection distances are useful for practical purposes, as these provide a simple rule of thumb to direct on-site interventions and are easy to implement. However, the literature shows that static buffers may fail to prevent fecal contamination due to complex hydrogeological and microbiological factors (Taylor et al., 2004). In practice, this means that human settlements dependent on shallow groundwater are bound to encounter water pollution problems sooner or later. The outcomes of this research show that plenty of work is needed to ensure that progress in sanitation does not compromise the quality of drinking supplies. In particular, developing standards for latrine siting would provide a welcome addition in many rural and periurban areas across sub-Saharan Africa. Alternatively, public latrines could be promoted over private latrines. This could however prove delicate, or even detrimental to public health, as it could be viewed as a backward step. Furthermore, the determinants for adopting latrine use over open defecation are complex and not completely understood (O'Connell, 2014; Thys et al., 2015).

The case at hand also suggests that relatively inexpensive solutions may exist. It is clear that operating and maintaining sewage systems is well beyond the means of the population, as most people live on less than one dollar per day. Besides, the area is fairly remote and there is a generalized absence of qualified technicians across the country. In contrast, piped water supplies (e.g. public standpipes) are relatively simple to operate, affordable for communities and have a solid record of providing good-quality water on a consistent basis. Thus, a sensible alternative to strike a balance between domestic wells and latrines would be to maintain the latrines while simultaneously discouraging people from drinking water from domestic wells, which could still be used for other purposes. Of course, this would imply the need to maintain the network in good working condition at all times. It would also be necessary to increase the number of water points, as most people refuse to walk the distance when improved water sources are located further than $500 \mathrm{~m}$ away from their homes (Martinez-Santos et al., 2017).

Water quality was largely overlooked in the context of the Millennium Development Goals, largely because monitoring was assumed from the outset to be "prohibitively expensive" and "logistically complicated" (UNICEF/WHO, 2012). In recent times, however, different authors are beginning to show that the cost of monitoring quality across sub Saharan Africa could actually be within reach, even if some practical matters are yet to be resolved (Delaile et al., 2017). Within this context, a complementary way to improve the quality of drinking supplies could focus on household-level water treatment, an issue that has been seldom studied in rural settlements of Africa. In this sense, our
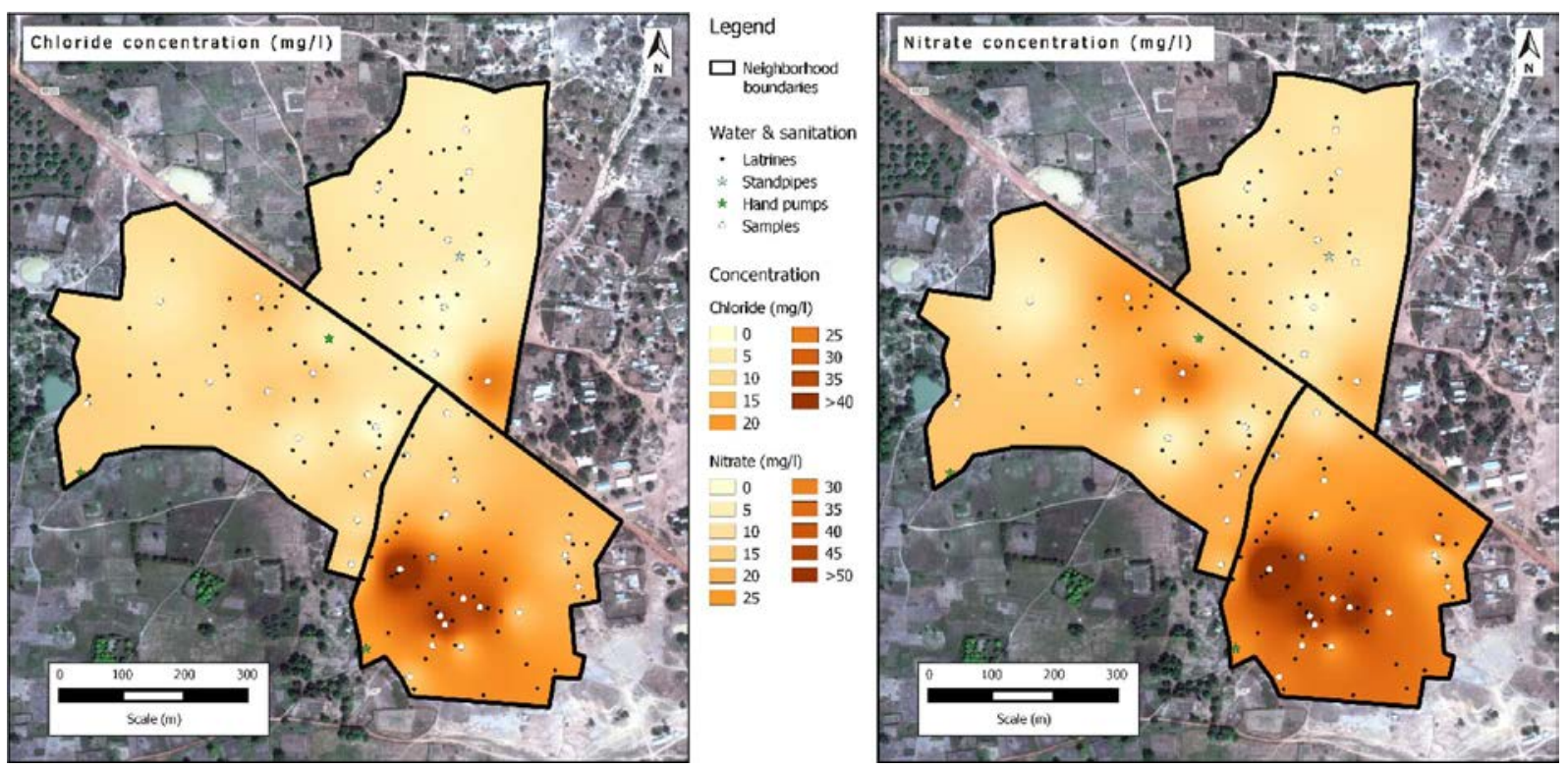

Fig. 5. Chloride and nitrate concentration as detected in field samples. 


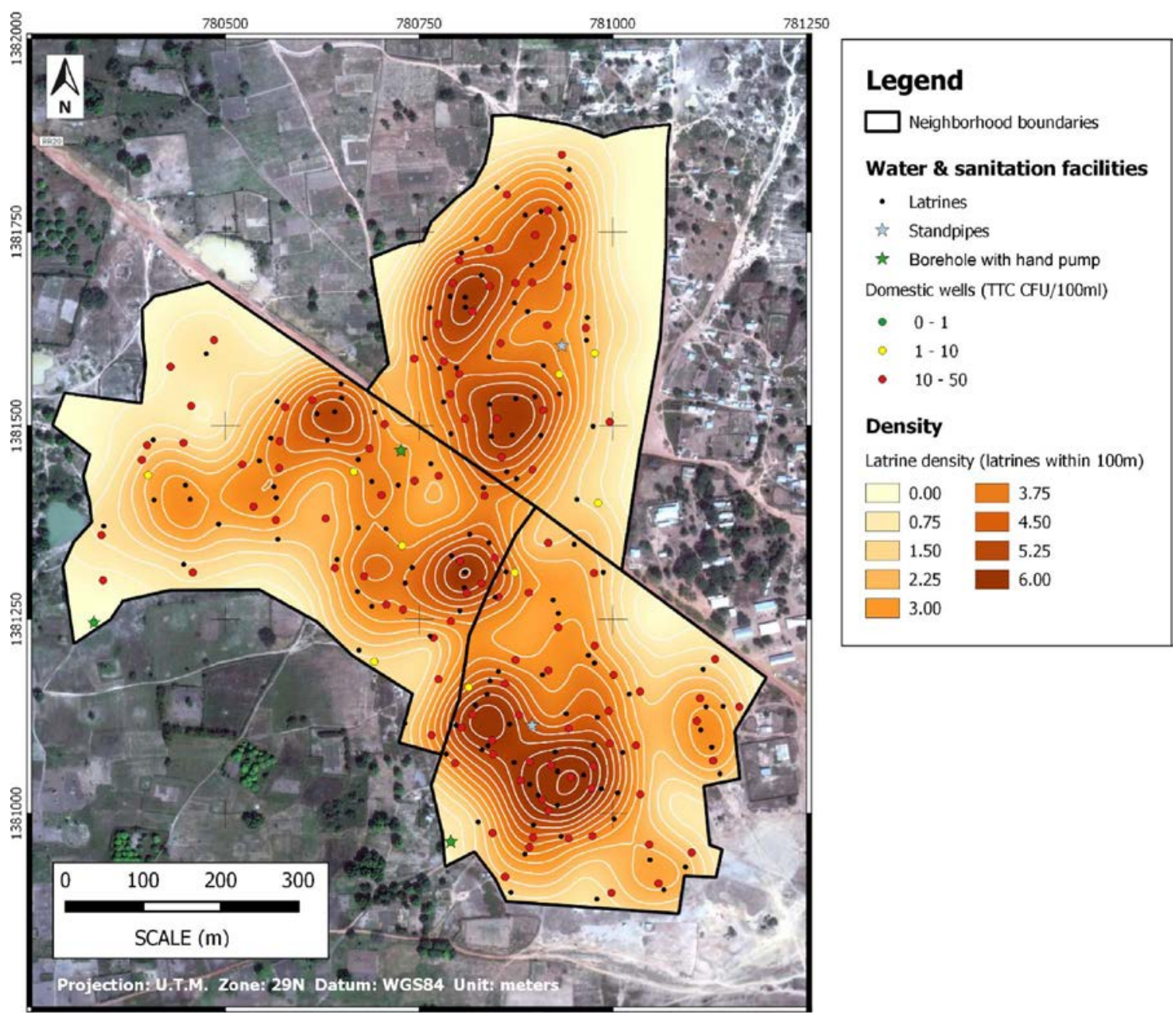

Fig. 6. Latrine density map. Results are expressed in terms of number of latrines or people within a 100-m radius.

research draws some novel insights as to how existing habits could be adjusted to mitigate the effect of fecal pollution in groundwater-dependent communities. In particular, the prevalence of decentralized treatment provides an additional understanding as to how groundwater supplies could be made safer. Indeed, the fact that nearly two-thirds of the households perform some kind of domestic water treatment suggests that there is a generalized awareness about the perils of drinking water from unimproved sources. It also means that acquired habits could evolve into supplementary firewalls to prevent the contamination of drinking supplies.

Two simple experiments were performed to check the degree of protection provided by domestic treatment. The first one consisted in chlorinating a bucket full of heavily contaminated well water (e.g. TTC too-numerous-to-count), and aimed at establishing how many droplets of bleach would be necessary to purify the content. Droplets were released on a two-at-a-time basis and allowed to mix for fifteen minutes prior to testing for residual chlorine. An Oxfam-Delagua water kit was used for this purpose (OXFAM, 2009). A relatively small volume of bleach (about ten droplets, i.e. $0.5 \mathrm{ml}$ ) was found to be enough to free the water from microorganisms. The second experiment consisted in chlorinating the well in the way most people do. An entire bottle of bleach (0.5 liters) was spilt into the same well, allowing it to mix for thirty minutes before testing. Total and residual chlorine were then measured periodically over the ensuing $24 \mathrm{~h}$. The first few measurements rendered some residual chlorine, but no trace was left after twelve hours. The well tested negative for TTC the following day and positive again $(>10)$ two days later.
These experiences are largely anecdotal. However, when coupled with the prevalence of fecal contamination in domestic wells, their outcomes demonstrate that domestic treatment procedures as performed by most of the local population (i.e. chlorinating the well) are largely ineffective. Chlorinating the bucket is not only more efficient from the microbiological point of view, but also cheaper in the long run. The bright side is that $57 \%$ of the population understands that there is a need to purify the water from domestic wells, even if the treatment method and/or the frequency are inadequate in most cases. Within this context, switching habits from chlorinating the well to chlorinating the bucket should be feasible. Remarkably, economic factors might be expected to favor this transition, as many respondents of the household survey admitted that they only chlorinated the well once in a while (e.g. once a month, once a year) because bleach is perceived to be expensive.

\subsection{Determinants for groundwater contamination}

Wright et al. (2013) developed an approach to correlate groundwater contamination to latrine and building density. An attempt was made to extend it by taking into consideration population and well density (Figs. 7 and 8). In this case, population is assumed to provide a more accurate proxy than building concentration, as the pollutant load ultimately depends on the number of people who use a latrine. Population-density estimates were developed as per the outcomes of the field survey. Well density was also taken into account, as most wells are unprotected and can be expected to act as sources of groundwater contamination. 


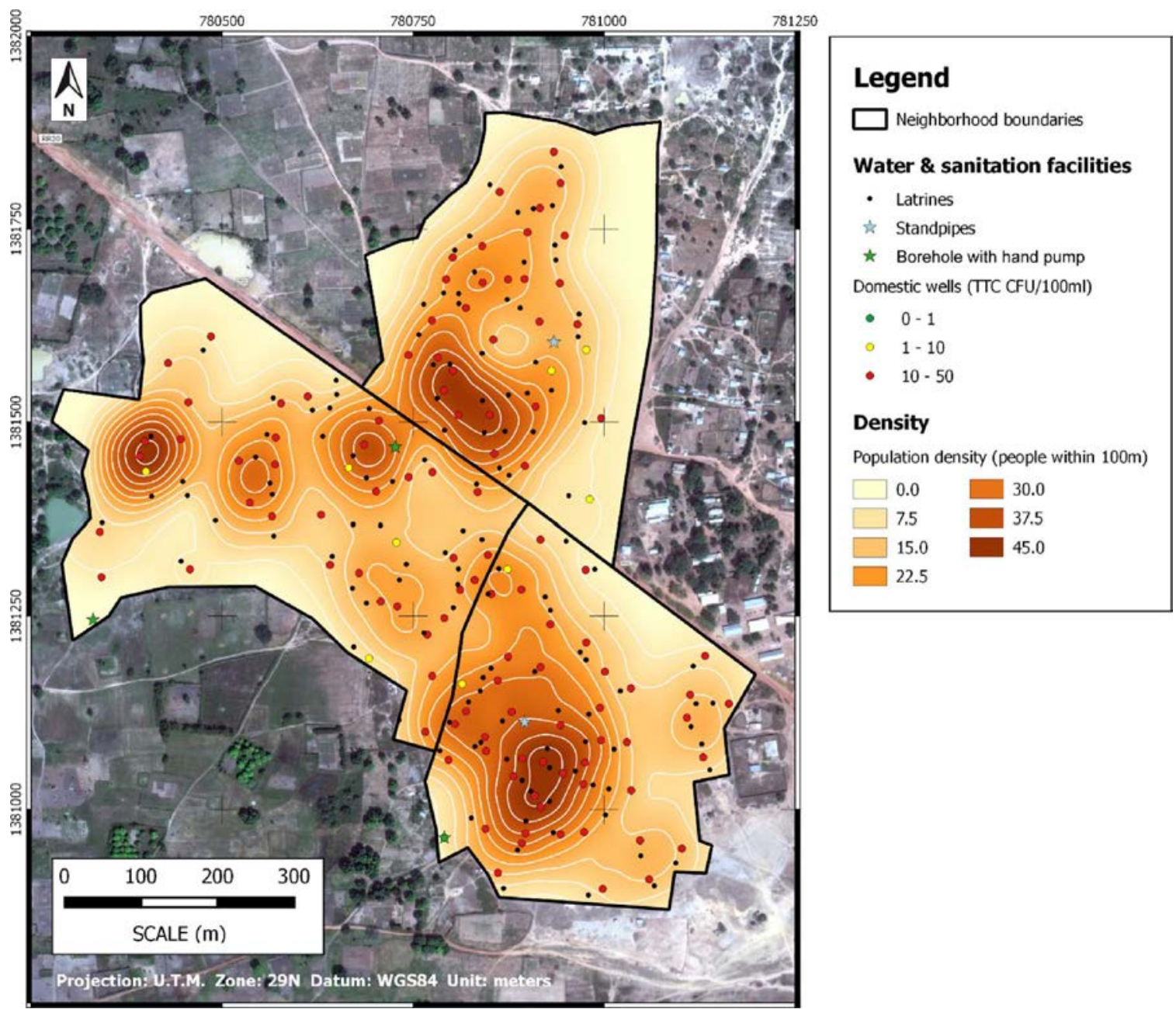

Fig. 7. Population density map. Results are expressed in terms of number of people living within a 100-m radius.

A shortcoming of our results is that over $70 \%$ of the samples rendered too-numerous-to-count TTC. The absence of precise quantitative data beyond the 50 TTC threshold hampers attempts to correlate coliforms with other relevant variables. Nitrate and chloride were thus used to complement the method. Several multiple regression models were run to determine the statistical significance of the three explanatory variables (e.g. latrine, population and well density) on TTC, nitrate and chloride content at all sampling locations. In absolute terms, multiple regression did not render significant statistical correlation for any of these variables. However, a more detailed analysis on a per neighborhood basis suggests that this approach can be useful at a more local scale. For instance, in the case of Diawarrala, latrine density is found to be a statistically significant predictor for nitrate $(\mathrm{r}=0.82, \mathrm{p}=0.02)$ and chloride concentration $(\mathrm{r}=0.94, \mathrm{p}<0.01)$ (Table 5). So was population density $(r=0.81, p=0.04$ and $r=0.94, p=0.03$, respectively). In the case of Fyenkala, latrine density was found to be a predictor of TTC $(r=0.73 \mathrm{p}=0.04)$ and a weak but significant correlation was found between well density and nitrate and chloride content in unprotected wells $(r=0.68, p=0.01$ and $r=0.70$, $\mathrm{p}=0.04$, respectively). Finally, population density is identified as a determinant for nitrate and chloride concentration in unprotected wells of Dougouyala Ouest $(r=0.85, p=0.04$ and $r=0.86, p=0.04)$. In other words, it appears that contamination in each neighborhood can be derived from different explanatory variables (latrine and population density in Diawarrala, latrine and well density in Fyenkala, population density in Dougouyala Ouest). Further work is needed to understand why, as no obvious reasons arise from observing the daily reality of the three communities on the field.

There is room for improvement in terms of the statistical adjustment between contaminant concentration and the explanatory variables. Several factors could be expected to add noise to the results. For one, there could be flaws associated with some of our basic assumptions. Take for instance how different studies demonstrate that owning or having access to a latrine does not ensure that it is used consistently by household members ( $\mathrm{O}^{\prime}$ Connell, 2014). This implies that, in some cases, the presence of a latrine may not necessarily translate into a pollutant load being released into the aquifer. Moreover, hydrogeological considerations could not be investigated directly. Although the area can be expected to be reasonably homogeneous, relatively small changes in porosity or permeability could result in preferential groundwater flows and dissimilar flow velocities at the local scale. In turn, these would constrain solute transport processes such as advective transport, diffusion or dispersion. Furthermore, the fact that most wells were unprotected suggests that contamination vectors other than subsurface flow could play an important role in TTC, nitrate and chloride concentration. This would also contribute to explain why wells located in sparsely populated areas with no theoretical latrine influence were found to be polluted.

\section{Conclusions}

On-site sanitation is widely promoted as a means to improve the living conditions of human settlements in low-income regions. While this provides a desirable alternative to open defecation, widespread use 


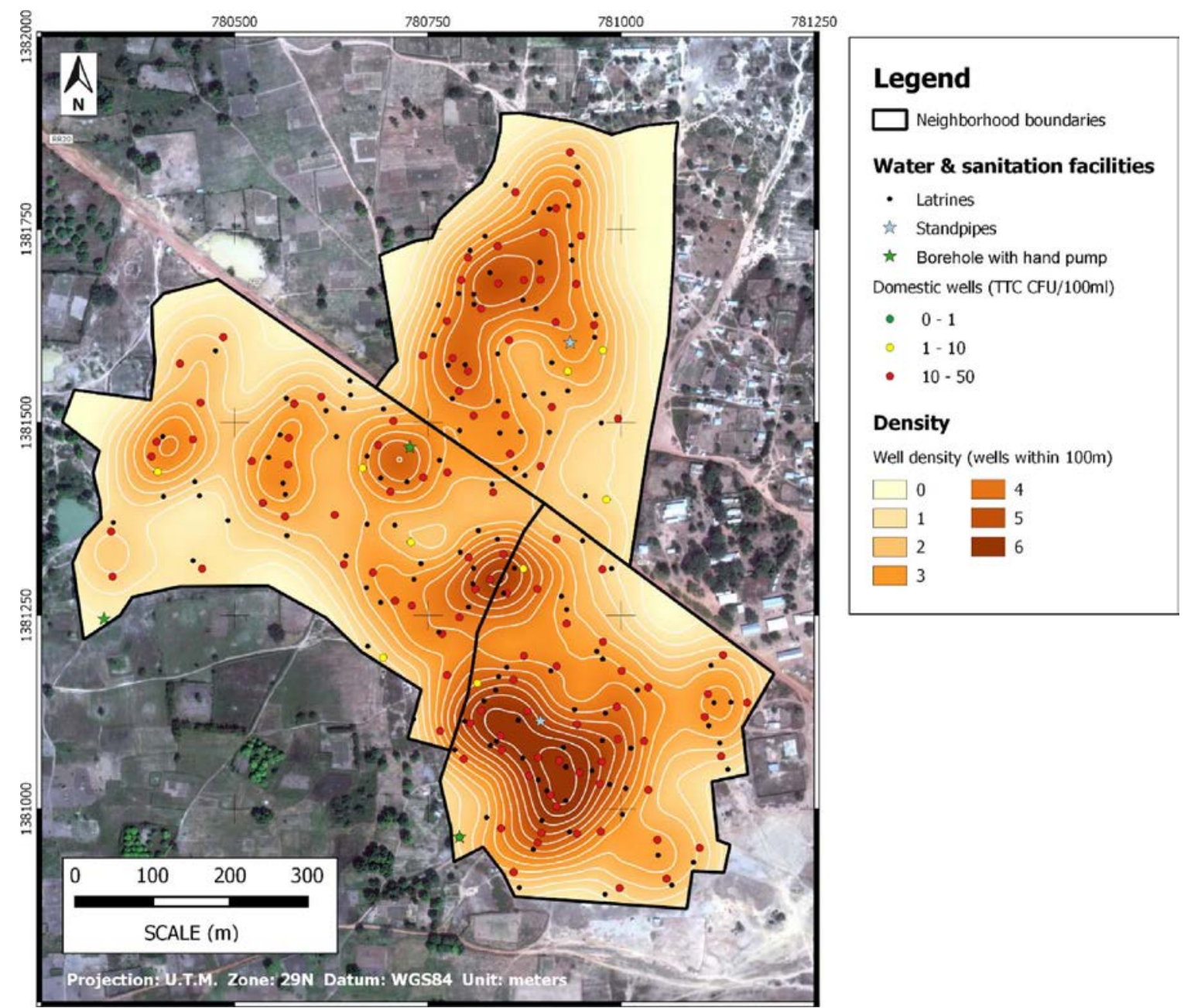

Fig. 8. Well density map. Results are expressed in terms of number of wells within a 100-m radius.

Table 5

Results of multiple regression models to predict $\mathrm{NO}_{3}$ and $\mathrm{Cl}^{-}$concentration based on $\mathrm{X}_{1}$ latrine density, $\mathrm{X}_{2}$ well density, $\mathrm{X}_{3}$ population density.

\begin{tabular}{lclllllllll}
\hline Neighborhood & $\mathrm{n}$ & $\begin{array}{l}\mathrm{NO}_{3} \\
\mathrm{r}\end{array}$ & $\begin{array}{l}\mathrm{X}_{1} \\
\mathrm{p}\end{array}$ & $\begin{array}{l}\mathrm{X}_{2} \\
\mathrm{p}\end{array}$ & $\begin{array}{l}\mathrm{X}_{3} \\
\mathrm{p}\end{array}$ & $\begin{array}{l}\mathrm{Cl}^{-} \\
\mathrm{r}\end{array}$ & $\begin{array}{l}\mathrm{X}_{1} \\
\mathrm{P}\end{array}$ & $\begin{array}{l}\mathrm{X}_{2} \\
\mathrm{p}\end{array}$ & $\begin{array}{l}\mathrm{X}_{3} \\
\mathrm{P}\end{array}$ \\
\hline Diawarrala & 17 & 0.82 & 0.02 & 0.38 & 0.04 & 0.94 & $<0.01$ & 0.50 & 0.03 \\
Fyenkala & 12 & 0.11 & 0.95 & 0.83 & 0.96 & 0.48 & 0.91 & 0.23 & 0.87 \\
Dougouyala O. & 11 & 0.50 & 0.55 & 0.23 & 0.59 & 0.51 & 0.32 & 0.94 & 0.80
\end{tabular}

of unlined pit latrines may result in hazardous side-effects. In particular, latrines have the potential to threaten shallow groundwater supplies such as springs or domestic wells. This is already generating new risk vectors which could pose a significant health hazard in the long run. Within this context, decentralized water treatment may offer a reasonably inexpensive means to make drinking water safer, but only if local populations are provided with adequate training and thoroughly made aware of the dangers of consuming polluted water.

This experience is widely representative of periurban and rural settlements across sub-Saharan Africa, and shows that establishing protection buffers for groundwater supplies in densely populated villages may sometimes be unfeasible. Within this context, there is a need to develop additional mechanisms to ensure that necessary sanitation practices do not compromise the quality of drinking water. In settings such as the one at hand, piped supplies may provide a sensible approach provided that groundwater is captured well outside populated nuclei and delivered to public or private standpipes. Furthermore, there is a need to develop funding schemes to ensure that water facilities are maintained in working condition, as well as to train technicians to monitor the quality of water supplies on a regular basis.

\section{Acknowledgements}

This research has been funded by the Agencia Española de Cooperación Internacional al Desarrollo (AECID), under grant numbers 2014/ACDE/005226 and 2016/ACDE/001953. For their time and support, the authors would like to thank Geólogos Sin Fronteras and two anonymous reviewers.

\section{References}

ARGOSS, 2001. Guidelines for assessing the risk to groundwater from on-site sanitation. British Geological Survey Commissioned Report CR/01/142. 97pp.

Cronin, A.A., Breslin, N., Gibson, J., Pedley, S., 2006. Monitoring source and domestic water quality in parallel with sanitary risk identification in northern Mozambique to prioritise protection interventions. J. Water Health 4 (3), 333-345.

Delaile, C., Peletz, R., Kumpel, E., Kisiangani, J., Bain, R., Khush, R., 2017. How much will it cost to monitor microbial drinking water quality in Sub-Saharan Africa? Environ. Sci. Technol. 51 (11), 5869-5878.

Dzwairo, B., Hoko, Z., Love, D., Guzha, E., 2006. Assessment of the impacts of pit latrines on groundwater quality in rural areas: a case study from Marondera district Zimbabwe. Phys. Chem. Earth. 31 (2006), 779-788.

Foster, S., Garduño, H., 2013. Groundwater-resource governance: are governments and stakeholders responding to the challenge? Hydrol. J. 21 (2), 317-320.

García-Castro, N., García-Rincón, J., 2017. Evaluación de la situación sanitaria en Beleko, Mali, y propuestas contra la contaminación microbiológica. Master Thesis. Posgrado de Experto en Agua, Saneamiento e Higiene en Cooperación Internacional. Universidad de Alcalá, Spain. 
Graham, J.P., Polizzotto, M.L., 2013. Pit latrines and their impacts on groundwater quality: a systematic review? Environ. Health Perspect. 121 (5), 521-530.

Harvey, P., 2007. Excreta Disposal in Emergencies: A Field Manual. WEDC, Loughborough University, UK ISBN 9781843801139.

Islam, M.S., Mahmud, Z.H., Islam, M.S., Saha, G.C., Zahid, A., Zulfiquar Ali, A.H.M. Hassan, M.Q., Islam, K., Jahan, H., Hossain, Y., Hasan, M.M., Cairncross, S., Carter R., Luby, S.P., Cravioto, A., Endtz, H.P., Faruque, S.M., Clemens, J.D., 2016. Safe distances between groundwater-based water wells and pit latrines at different hydrogeological conditions in the Ganges Atrai floodplains of Bangladesh. J. Health Popul. Nutr. 35, 26

Kiptum, C.K., Ndambuki, J.M., 2012. Well water contamination by pit latrines: a case study of Langas? Int. J. Water Resour. Environ. Eng. 4 (2), 35-43.

Liddle, E.S., Mager, S.M., Nel, E.L., 2015. The suitability of shallow hand dug wells for safe water provision in sub-Saharan Africa: lessons from Ndola Zambia. Appl. Geogr 57, 80-90.

MacDonald, A., Davies, J., Calow, R., Chilton, J., 2005. Developing Groundwater A Guide for Rural Water Supply. ITDG Publishing ISBN 185339596 X.

MacDonald, A.M., Davies, J., Calow, R.C., 2008. African hydrogeology and rural water supply applied groundwater studies in Africa. In: In: Adelana, S.M.A., MacDonald, A.M. (Eds.), IAH Selected Papers in Hydrogeology, vol. 13 CRC Press, Taylor \& Francis, UK.

Machado, A., Bordalo, A.A., 2014. Analysis of the bacterial community composition in acidic well water used for drinking in Guinea-Bissau, West Africa? J. Environ. Sci. 26 (8), 1605-1614

Martinez-Santos, P., Cerván, J.A., Cano, B., Díaz-Alcaide, S., 2017. Water versus wireless coverage in rural Mali: links and paradoxes. Water 9 (6), 375

Martinez-Santos, P., 2017. Does $91 \%$ of the world's population really have sustainable access to safe drinking water? Int. J. Water Resour. Dev. 33 (4), 514-533. http:/ / dx. doi.org/10.1080/07900627.2017.1298517.

Mkandawire, T., 2008. Quality of groundwater from shallow wells of selected villages in Blantyre District, Malawi. Phys. Chem. Earth Parts A/B/C 33 (8-13), 807-811.

Nienie, A.B., Sivalingam, P., Laffite, A., Ngelinkoto, P., Otamonga, J.P., Matanda, A., Mulajic, C.K., Biey, E.M., Mpiana, P.T., Poté, J., 2017. Microbiological quality of water in a city with persistent and recurrent waterborne diseases under tropical subrural conditions: the case of Kikwit City, Democratic Republic of the Congo. Int. J. Hyg. Environ. Health 220 (2017), 820-828.

Nyenje, P.M., Foppen, J.W., Kulabako, R., Muwanga, A., Uhlenbrook, S., 2013. Nutrient pollution in shallow aquifers underlying pit latrines and domestic solid waste dumps in urban slums. J. Environ. Manage. 122 (2013), 15-24.

O'Connell, K., 2014. What Influences Open Defecation and Latrine Ownership in Rural Households? Findings from a Global Review International Bank for Reconstruction and Development. The World Bank, Washington.

OXFAM, 2009. Oxfam Delagua Portable Water Testing Kit. User Manual. University of Surrey, Guildford UK 65p.

Okotto, L., Okotto-Okotto, J., Price, H., Pedley, S., Wright, J., 2015. Socio-economic aspects of domestic groundwater consumption, vending and use in Kisumu, Kenya. Appl. Geogr. 58 (2015), 189-197.

Parker, A., Carlier, I., 2009. National Regulations on the Safe Distance Between Latrines and Waterpoints DEW Point. Report. 6p.

Pritchard, M., Mkandawire, T., O'Neill, J.G., 2008. Assessment of groundwater quality in shallow wells within the southern districts of Malawi. Phys. Chem. Earth Parts A/B/C 33 (8-13), 812-823.

SASPlanet, 2014. SASPlanet Software. Version 141212.8406. SASPlanet Development Team. www.sasgis.org. Last accessed: 15 January 2017

Shivendra, B.T., Ramaraju, H.K., 2015. Impact of onsite sanitation system on Groundwater in different Geological settings of Peri Urban areas. Aquat. Procedia 4 (2015), 1162-1172

Sorensen, J.P.R., Sadhu, A., Sampath, G., Sugden, S., Dutta Gupta, S., Lapworth, D.J., Marchant, B.P., Pedley, S., 2016. Are sanitation interventions a threat to drinking water supplies in rural India? An application of tryptophan-like fluorescence. Water Res. 88 (2016), 923-932.

Taylor, R., Cronin, A., Pedley, S., Barker, J., Atkinson, T., 2004. The implications of groundwater velocity variations on microbial transport and wellhead protection review of field evidence. FEMS Microbiol. Ecol. 49, 17-26.

Thys, S., Mwape, K.E., Lefèvre, P., Dorny, P., Marcotty, T., Phiri, A.M., et al., 2015. Why latrines are not used: communities' perceptions and practices regarding latrines in a Taenia solium endemic rural area in Eastern Zambia. PLoS Negl. Trop. Dis. 9 (3), e0003570. http://dx.doi.org/10.1371/journal.pntd.0003570.

UNICEF, 2014. The rights to safe water and to sanitation. UNICEF Curr. Issues 3, 1-5.

UNICEF/WHO, 2009. Diarrhoea: why children are still dying and what can be done. UNICEF and World Health Organization Report. ISBN 978-92-806-4462-3. 58p.

UNICEF/WHO, 2012. Progress on Drinking Water and Sanitation: 2012 Update. Report, 66p. ISBN: 978-92-806-4632-0.

UNICEF/WHO, 2015. The Millennium Development Goals Report. (Report). Author, New York, NY 75pp.

United Nations, 2015a. Water for a Sustainable World. The United Nations World Water Development Report 2015. United Nations World Water Assessment Programme. UNESCO, Paris.

United Nations, 2015b. Transforming Our World: the Agenda for Sustainable Development. General Assembly of the United Nations Resolution A/RES/70/1.

WHO, 2002. Environmental Health in Emergencies and Disasters: A Practical Guide World Health Organization Geneva, Switzerland 252p. ISBN 92-4-154541-0.

WHO, 2011. Guidelines for Drinking-water Quality. World Health Organization Geneva, Switzerland 541p. ISBN 9789241548151.

WHO, 2017a. Diarrhoeal Disease. Fact Sheet. World Health Organization website. Last accessed: 21 July, 2017

WHO, 2017b. Sanitation. Fact Sheet. World Health Organization website. Last accessed: 21 July, 2017.

Wanke, H., Nakwafila, A., Hamutoko, J.T., Lohe, C., Neumbo, F., Petrus, I., David, A., Beukes, H., Masule, N., Quinger, M., 2014. Hand dug wells in Namibia: an underestimated water source or a threat to human health? Phys. Chem. Earth Parts A/B/C 76-78 (2014), 104-113.

Wright, J.A., Cronin, A., Okotto-Okotto, J., Yang, H., Pedley, S., Gundry, S.W., 2013. A spatial analysis of pit latrine density and groundwater source contamination. Environ. Monit. Assess. 185 (2013), 4261-4272. 